\title{
Can Computers Motivate? The Association Between End User Computing Levels, Job Motivation, And Job Core Characteristics: A Field Study
}

Robert M. Barker, (E-mail: rmbarker@ louisville.edu), University of Louisville Andrew L. Wright, University of Louisville

\begin{abstract}
While end user computing (EUC) has been studied from the standpoint of classification and management, less attention has been placed on how the utilization of the technology impacts on users jobs. This study proposes that differing levels of EUC activity will be associated with differing levels of job characteristics and computer related job outcomes. The study focused on the jobs of 121 middle managers and professional workers enrolled in an MBA program at a southeastern university. The study finds that with successive levels of complexity in EUC utilization, there are corresponding increases in the levels of users' experiencing of job core characteristics.
\end{abstract}

\section{Introduction}

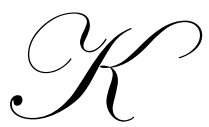

nowledge workers, those workers whose contribution to their organizations is primarily intellectual (Mcleod, 1993), in today's business organizations face a vastly different work life than existed as little as five years ago. Information technology has penetrated almost all aspects of these workers environments, from the routine utilization of electronic mail and Internet browsers, to reliance on personal productivity software and laptop personal computers for data analysis and report generation. The greatest difference in these workers jobs has been the increased reliance on end user computing (EUC), which, in most organizations, has become a customary part of many office worker's jobs (Van Kirk, 1995). EUC has been defined as the application of computing resources for the purpose of producing information, by the consumer of that information (Barker, 1993). The pervasiveness of EUC can be attributed to many forces: the steep decline in the cost of microcomputing hardware, the rise in the computing literacy of users, and the wide expansion in the availability of easy to use software products. Organizations have begun to give users increasing latitude in accessing organizational data stores and greater discretion in computing choices. Combined, these two trends have enabled users to attack information insufficiencies in ways that could not have been envisioned in the past. This proliferation of EUC will result in a workplace where knowledge workers can expect to interact with the technology on a daily, if not hourly, basis. With the introduction and increased use of new object-driven and browserbased software technologies, this trend will only intensify for the foreseeable future.

Research into this phenomenon has typically centered in two areas: subject centered studies examining EUC use; or EUC management issues, examined from the perspective of information technology professionals. Examples of subject centered topics would include such areas as end user productivity (Palvia, 1991; Ngwenyama, 1993), facilitating utilization in user groups (Cheney et al., 1986; Gerrity and Rockart, 1986; Brown and Bostrom, 1989; Hackathorn,

Readers with comments or questions are encouraged to contact the authors via email. 
1988), EUC training and support (Nelson and Cheney, 1987; Sein and Bostrom, 1987; Bostrom et al., 1990; Hayen et al., 1990), or satisfaction with EUC (Doll and Torkzadeh, 1988; Bergeron and Berube, 1988; Igbaria et al., 1989; and Nelson, 1990). EUC management issues have included examining user developed applications (Rivard and Huff, 1984, 1985), managing risks associated with EUC (Alavi and Weiss, 1985), EUC implementation (Rivard, 1987), benefit maximization (Munro, 1988; Bergeron and Berube, 1988), EUC standards (Amoroso, 1988; Karten, 1991), and EUC policies (Galetta and Hufnagel, 1992).

While this research has greatly advanced the understanding of EUC, less attention has been focused on the confluence of technology and actual job characteristics; the influence of EUC activities on the user's work. EUC, after all, is the utilization of an information technology as an addition to a knowledge worker's job, in an effort to supplement organizational information sources. This study examines the interaction between the level and intensity of EUC activity and its affect on resulting user perceived job motivation, as well as job characteristics experienced from those differing levels of EUC utilization.

The following sections will outline the relevant research issues, describe the research methodologies and tools, summarize the results of the tests used, and offer conclusions and future directions for subsequent research.

\section{EUC and Users' Work}

While the literature is in agreement that EUC is an issue of importance to IT professionals and knowledge workers (Benjamin, 1982; Davis and Olson, 1985; Brancheau and Wetherbe, 1987; Deans et al., 1991), there is little agreement in the literature on a specific definition of the term. Martin $(1982,1984)$ has differentiated between two classes of EUC: direct use and indirect use. Direct users would be typified as those users who actually write their own applications programs and perform their own systems development, whereas indirect users will only interact with the technology by using the information the technology produces. This definition is so broad that almost every user in an organization would be an indirect user. Davis and Olson (1985) have defined EUC as the capability of users to have direct control over their computing needs. This definition does not, unfortunately, describe what the term "control" entails. Panko (1987) has defined EUC as an environment where the user has free control and latitude over the process of information production. This definition does address some degree of interaction, but stops short of describing the interaction.

The commonality between these definitions is that the user is somehow interacting in the production of information, whereas in the past the user was not necessarily involved with an information system beyond the reception of information. The traditional approach to systems was to have the information systems in the organization provide information for the user, putting the user in a more or less passive situation in the production of the information. EUC demands a more active user role, and implies that the systems require more user interaction. Thus, for the purposes of this study, EUC will be defined as the application of computing resources for the purpose of producing information by the consumer of that information (Barker, 1992). By using this definition, all EUC considered in this study will involve the direct utilization of the technology by the user, and the outcome of that interaction will be utilized by the user. If the user is engaged in the production of the information, and then applies that information to support work duties, the utilization of EUC can be viewed as an addition to the user's job. That addition is reflected by a change in work requirements, and makes information available to the user that otherwise would not be.

Given this, it is hypothesized that the user is affected by the presence of EUC activity in the job in two aspects. The first would be a positive effect on job responsibilities through the addition of utilizing the technology. The second effect the user would experience arises from the consumption of information, which is the product of the EUC utilization. The interaction between the user and satisfaction with the EUC activity has been investigated by Doll and Tokzadeh (1988). The interaction between EUC activity and task characteristics has previously been studied by Yaverbaum (1988) and Medcorf (1989). When differences between the jobs of users and nonusers are considered, the presence of EUC has been found to be a job enrichment. This definition of enrichment is consistent with definitions by Hackman and Oldham (1976, 1980). This job enrichment will occur as certain characteristics are added to a job which make it more motivating and satisfying to the person performing that job. As mentioned above, EUC provides such enrichment by adding content to jobs, as well as providing users with additional information that otherwise would not be available. 
The content that EUC adds to a job can be examined more closely by decomposing the job and scrutinizing the effect EUC has on the job's core characteristics. Hackman and Oldham $(1976,1980)$ developed a theory of work design that is based on the finding that worker motivation can be enhanced by increasing the levels of responsibility, meaningfulness and feedback in the job that a worker performs. These levels are represented by that job's five core characteristics: skill variety, task identity, task significance, perceived autonomy, and the amount of feedback received about work outcomes. Skill variety refers the number and diversity of abilities necessary to perform a job. Task identity is degree to which the job requires a completion of a whole or identifiable piece of work. Task significance is degree to which the job has a substantial impact on the lives of others. Perceived autonomy is the degree to which the job allows for freedom, discretion, and worker independence. Feedback on work performance is the amount and type of information provided about job performance. It is possible to reliably measure such characteristics using the Job Diagnostic Survey (JDS), which was developed and extensively validated by Hackman and Oldham (1980), and has been used in subsequent information systems research by Franz et al. (1986), Yaverbaum (1988) and Medcorf (1989). Collectively, the five characteristics measure the motivating potential score (MPS) for a job, which is calculated with the following formula:

MPS $=[($ Skill Variety + Task Identity + Task Significance $) / 3] *$ Feedback $*$ Autonomy

The presence of these characteristics may be moderated by other factors, such as a lack of the skills and knowledge necessary to perform the job, dissatisfaction with the work's physical context, and a lack, on the part of the worker, to need to be challenged by the work (growth need strength). See Figure 1 for an illustration of this model. Studies have demonstrated that increasing levels of the five core characteristics in a job increases worker motivation, enriching the job. This distinction is important because enriched work environments have been associated with increased job satisfaction, greater productivity, and decreased employee turnover and absenteeism (Hackman and Oldham, 1980; Daft, 1981).

The first issue to be examined here is to determine if EUC levels are associated with differing levels of job motivation, suggesting it does enrich a job. Secondly, if the first association is significant, how are differing EUC levels associated to differing levels of core job characteristics described by Hackman and Oldham? It seems intuitively obvious that EUC, by providing information which might not otherwise be available to a worker in a job, and by adding additional tasks to the job which are desired by the user (i.e. user-pulled), EUC will enrich a job. This is the general finding of Yaverbaum (1988) and Medcorf (1989), when the jobs of users and nonusers are compared. While there may be some agreement that EUC is a job enrichment, the degree of the enrichment has not been established; nor have differences in level of EUC activities been considered. EUC is not a generic user activity; differences between levels of EUC activities and sophistication have been well summarized by Blili et al. (1996). One of the most cited taxonomies was developed by Rockart and Elannery (1983), and are summarized in Table 1. This study will consider EUC activity at the first three levels of EUC described by Rockart and Flannery as defining three different levels of sophistication in EUC as an addition to a job. In the latter three levels of Rockart and Flannery's taxonomy, the EUC comprises the majority of the job duties, which does not allow for the differences sought here.

It is hypothesized that differing levels of EUC will add differing levels of enrichment to a job; by affecting each of the five core characteristics of the job the user performs. Nonusers, non-programming end users, command level users and end user programmers should have varying levels of skill variety, given the variety in their computing activities. As so many researchers have stressed the need for EUC training (Eason, 1984; Henderson and Treacy, 1986; Sumner and Klepper, 1987; Karten, 1987 and 1988; Hayen et al., 1990), the addition of these skills must be critical to the users' ability to utilize the technology. As movement is made from the lowest level of computing technology to the greatest, the levels of skill variety should positively increase. The same progression in characteristic intensity should also be evident in task identity. Computing allows the user task with a beginning, middle, and end. At the conclusion of the interaction, there is a tangible result of that user's effort, which is the information that user receives. With greater complexity in the interaction, the degree of task identity should correspondingly increase.

The effect on task significance should be the same. Use of a computer has previously been associated with greater feelings of self-competence (Morieux and Sutherland (1988), and perception of enhanced status in the organiza- 
tion (Safayeni et al., 1988). Greater complexity in that computing, it may be theorized, would add to those feelings of competence and status. Given that control over information was cited as the original motivation for EUC (Rivard and Huff, 1984, 1985, 1988), EUC should add to feelings of personal autonomy. Greater sophistication in that computing should add successive levels of autonomy. The utilization of the computer should also add to the amount of feedback the user receives. As stated before, use of the computer is a discrete activity. At the completion of the activity, the user is given results, be they from a query, a program or electronic mail. With more sophistication in the use, there should be correspondingly greater amounts of information received.

Differences in computing complexity, therefore, should result in differing experiencing of job characteristics, and thus corresponding differences in MPS for the different EUC levels. These assertions can be summarized with the following hypotheses, expressed in null form:

Ho: There are no differences between user motivating potential means at differing levels of end user computing complexity.

Ho: There are no differences between user perceived job characteristics means at differing levels of end user computing complexity.

The following section will outline the research method used to test these hypotheses, the data instruments used, and the subjects who participated in the study.

\section{Research Method}

To test these hypotheses, the research methodology used in this study is that of a survey based field study. Subjects who utilize EUC in their jobs were surveyed on their computing habits, their affective responses to that use, and perceptions of job core characteristics via a composite data instrument. The data collected was then analyzed for descriptive purposes; the subjects were assigned to their respective levels of EUC activity. The responses were then aggregated, group means were calculated and compared, and statistical tests performed to check for inter-group differences. The following sections will outline each of these areas in more detail.

\section{Description of Subjects}

The subjects used in this study are graduate students enrolled in an evening MBA program at a leading university in the southeast. These students are primarily part-time working students, as the majority of them are middle managers and working professionals. These students were found to be an excellent group to study, as informal surveys established that the majority of these students commonly utilize EUC as a part of their jobs. In addition, as graduate students, this group has a common educational background, and are required by the MBA admission standards and curriculum to have a common set of computer and business skills. These skills are necessary to enter the program and complete degree requirements. If a student lacks these skills, that student must complete a remedial course to attain them. When asked with what frequency computer use was required by their work, the overwhelming majority of the students responded that such use was a daily part of their jobs. Thus, these students have both the skills and access to the software and hardware tools necessary to perform EUC.

The survey instrument was distributed to students in a graduate management information systems course. Subjects were informed that the survey was anonymous, and the statistics gathered were for summary purpose only. The survey was administered in five sections of 30 students, over a three-semester period. While this is not a true random sampling technique, the subjects represented a rich cross section of different organizations and industries, and assignment to the course was essentially random. For a summary of subjects, see Table 2. Participation was voluntary, and no course credit was offered as inducement to complete the survey. A total of 150 questionnaires were distributed.

The subjects used in this study were identified by their questionnaires as either middle managers or professional workers. Subjects excluded from the sample included any clerical or administrative support personnel, and full time 
(i.e. non-working) students. Clerical workers and administrative staff personnel were excluded because of the differences in their work duties as compared with middle managers and professional workers. Clerical workers typically use office automation technology, which is very similar to EUC in skill requirements. Their remaining job characteristics, however, would be so greatly dissimilar from middle managers and professional workers, and would likely bias the measurement of the associations sought. Full time students were eliminated from the sample because they would not have current professional work responsibilities, which renders the ability of the instrument to measure core job characteristics moot.

Each subject completed a composite instrument, consisting of the Job Diagnostic Survey (JDS), background questions about age, education, employment level, computer utilization, and affective questions concerning their reactions to job core characteristics. The JDS was chosen because of its widespread use and acceptability (Yaverbaum, 1988), and to allow for greater comparability to past studies, as per the suggestions of Jarvenpaa et al., 1985. Based on responses in the questionnaires, subjects were assigned to one of the three levels of EUC activity described by Rockart and Flannery (1983). Sample sizes within the levels were found to be sufficient for statistical power in the ANOVA tests (Baroudi and Orlikowski, 1989). Determination of EUC activity was based on responses to Likert-type questions concerning frequency of employment of common EUC software in the normal course of the subjects' jobs. The scores indicating the greatest frequency of the highest level of EUC utilization determined the EUC level into which the user was assigned. This approach is adapted from Igbaria et al (1989). For example, if a subject indicated that he or she used electronic mail and word processing most often, that user was assigned to nonprogramming end user status. Frequent use of spreadsheet and/or graphics indicates command level use, while employment of a procedural language or 4GL would indicate an end user programmer. It is important to note that the most salient element in this study is the EUC level at which the subject actually performs most often, not the level of which the subject is capable of performing, by virtue of prior training or experience. If a non programming end user is capable of being an end user programmer but does not actively perform at that level, the possibility of the EUC contributing to that subject's job characteristics would be much less likely than the daily contribution of actual command level or non programming end user activity. Thus, assignment to a level is dependent on at least daily utilization of the technology, and of the highest degree of sophistication in that use.

\section{Data Analysis}

Once the subjects had been assigned to the levels of EUC utilization indicated by their questionnaires, hypotheses testing was initially performed using summary statistics and ANOVA techniques. ANOVA testing methods check for the differences between group means to analyze whether those means are all drawn for the same population. Null hypotheses for this method state that all means for the three levels are statistically the same; implying that statistical differences are so small that the groups must be drawn from the same population. If the group means are dissimilar, it suggests that the groups are drawn from different populations, and their differences in responses are therefore based on their utilization of the technology. For this study, the null would state that there are no differences in the means for the job core characteristics of users at different levels of EUC utilization, implying that the users in the three groups experience their jobs the same, and that the presence of EUC has little contribution to their work. The null would also state that the computing related outcomes for the three groups are the same, that there are no differences between the three groups reactions to the EUC in their jobs. Because the sample used here is one of convenience, and was not drawn in a truly random fashion, there can be some question about the results reported here. For the purposes of this study, we must assume that the subjects are drawn randomly from the population of working middle managers and professional workers.

To test these hypotheses, JDS mean scores for the five job core characteristics were calculated, as well as means for subject MPS. The response means were calculated, and differences were estimated using .05 probability. The general linear model was used to estimate group means due to the uneven cell sizes for the utilization levels.

If the results show that the means are significantly different, it is necessary to ascertain which means are individually different from the others. ANOVA techniques will report differences between the means as groups, but do not report which individual groups are different. It could be the case that two of the groups are significantly different, but the third is not significantly different from one of the latter two. Such testing was performed using post hoc analysis techniques once differences were found. In this study, the post hoc analysis for significant differences among means was 
conducted using Scheffe's test for pairwise comparisons, which, again, is appropriate for uneven cell sizes. These differences were tested at a .05 level of significance. The following section outlines the mean estimates, and the results of the hypotheses testing.

\section{General Results:}

Table 3 summarizes the results of the JDS related means reported for the entire group of subjects used in this study and the JDS related mean scores for the individual groups of EUC utilization. As hypothesized, there are monotonically increasing scores reported for MPS in the three groups of utilization. When comparing the mean scores reported for individual core job requirements, skill variety, feedback, autonomy, and task identity scores increase as levels increase. The only core job characteristic which does not increase with this relationship is task significance, nor do scores for subject growth need strength increase with increasing sophistication in EUC activity. Results of ANOVA testing found significant differences between mean scores for skill variety and task identity, weaker differences for the means scores of feedback. The means for task significance and autonomy were not found to be significantly different.

Scheffe's post hoc testing for skill variety reported significant differences between end user programmers and nonprogramming end users, but not for command level users and either end user programmers or nonprogramming end users. Results of Scheffe's testing for task identity were similar to those for skill variety, although here there were also differences between nonprogramming end users and command level users. The results for feedback are the same as for skill variety; significant differences for end users programmers and nonprogramming end users. The Scheffe's test for subject growth need strength found significant differences for command level users and nonprogramming end users, but not for end user programmers and non programming end users. See Table 5 for summarized results.

Mean scores for user perceived computing outcomes were also calculated. Scores at the different levels of EUC utilization are presented in Table 6. The scores for these outcomes all increase as EUC complexity increases, although the perceptions of increased job responsibility attributed to the utilization of EUC in the job increase is very slight between nonprogramming end users and command level users. Results of ANOVA testing finds significant differences for all user perceived EUC outcomes with the exception of increased job responsibilities. See Table 7 for summarized outcomes of these tests.

Scheffe's post hoc testing for user perceptions of job outcomes shows significant differences between end user programmers and nonprogramming end users for work performance, interesting work, control of work, challenging work, greater efficiency, and decision performance. In addition, for work performance there is also a significant difference between nonprogramming end users and command level users, although not between command level users and end user programmers. See Table 8 for a summary of the Scheffe's testing.

\section{Summary and Conclusions}

Perhaps the most striking finding in this study is the difference between MPS means at the three levels of utilization. As was hypothesized, the means are significantly different, and positively increasing. The magnitude of the difference, while not overwhelming, does indicate that there is a small to medium size effect for the presence of EUC in a job. The same is true for most of the means of the individual job core characteristics. The means for skill variety, task identity and the amount of feedback received on job results show, for the most part, positive increases in means as the level of EUC complexity increases. The results here demonstrate that EUC does indeed add to the characteristics that users experience in their job, although the strength of effect on the characteristics is, again, a small effect. The differences noted seem intuitively obvious. When there are differences in the complexity of EUC use, there should be differences in the variety and number of skills necessary to perform a job. Access to such technology allows users much more feedback about their work performance, since the actions with the technology are information- producing actions. The increases in task identity are perhaps due to feelings of greater computing competence and a function of access to greater amounts of information. The lack of an association for increased task significance could be a function of the familiarity that workers today have with computer; the skills may have become so commonplace that there is no longer a halo effect around the computer's use. A lack of an association for increased autonomy could be due to the fact that the presence of 
EUC does not address the issues of personal freedom to the extent that, for example, more control over decision-making would.

Based on the results of the hypotheses testing, the presence of EUC influences the managers' experiencing of computer related outcomes. The results of the hypothesis testing demonstrate significant differences in the means for enhanced work performance, creating more interesting work, affording greater control of work, making the work more challenging, increasing efficiency in their work and enhancing decision making. The greatest magnitude of difference was found between the nonprogramming end users and the end user programmers for all association except enhanced work performance, where the nonprogramming end user also differed with the command level users. It seems intuitively obvious that as EUC adds content to these workers jobs, it also influences their perceptions of the job as well. The fact that the end user programmers seem to experience these outcomes the most strongly could be due to the fact that the EUC activity puts much greater demands on the worker than the less sophisticated utilization.

The implications of these findings must be taken somewhat cautiously. The sample used was one of convenience, and may or may not be representative of the population as a whole. Additional testing should be done with other groups to further validate these results. The fact that these managers are also MBA students may bias the results, in that these students all have a requisite level of EUC skills, as required by the MBA curriculum, whereas other groups of managers may lack these skills altogether. Additionally, this study does not take time into account as a specific variable of interest. It may be the case that the associations noted here may be attenuated with the passage of time, or the introduction of newer tools. Lastly, the data could simply be reflecting the natural differences between job core characteristics inherent between different types of jobs, implying that the subjects are, in reality, dissimilar units. The likelihood of this actually being the case is very slight, as the data was carefully screened to ensure that the subjects were all of similar jobs levels and educational backgrounds.

Some conclusions can be drawn from the data, however. The data demonstrate that, for this group of users, there are clear differences between the way users at differing levels of end user computing activity experience their jobs, and the results from utilizing the computer. For example, if executive management were concerned with finding those employees who were the most motivated in an organization, a point of first departure for such a search could be initiated by first examining computing activity. It also appears that the investment made in EUC technologies, which have been considerable in recent years, have the effect of creating more robust and motivating work for the workers who use it. Indeed, it may be in the best interests of these organizations to offer training to their employees to encourage them to become more sophisticated users. Thus, some stake in training for these users would, perhaps, be funds well invested in keeping those workers motivated by their jobs.

From an organizational standpoint, the implications may be more profound. EUC may hold a means to influence worker motivation levels in a more cost effective manner than those used in the past. More traditional approaches to increasing worker motivation include rotating workers among different jobs, which has a high training cost; increasing worker compensation levels or offering monetary bonuses; and promoting workers to higher in the organization with attendant changes in compensation and benefits. Hackman and Oldham (1980) have linked increased motivation to increases in job productivity and greater job satisfaction, which are associated with decreases in turnover and worker absenteeism. Given that EUC may have some impact on worker motivation, organizations may have the means to exert some control over these costs - by encouraging workers to utilize EUC at higher levels.

\section{Suggestions for Future Research}

Based on the data in this study, there does appear to be an association between the level of EUC activity in a job and the manner in which a worker perceives job characteristics and outcomes. The analysis of this sample demonstrates that the associations are positive and of increasing strength as differences are noted from lower levels of computing to higher levels. There are many implications for future research resulting from this study. For example, it is obvious that the state of the art in end user computing changes quite rapidly, and this study does not explicitly address time as a variable. As mentioned above, the association between the technology and the user may attenuate over time. A future study could examine this. 
Additionally, this study considers only workers drawn from the United States. It would be interesting to see if the association between the end user computing technology and workers in non-domestic workplaces is the same abroad as it is in the United States. Attitudes toward computing use may prove to be different is a work context where such use is more novel or unusual, such as in a country like Panama or Greece, or in a country where such use is even more standard, such as Singapore or Hong Kong.

Finally, this study does not seek to establish the causal direction of the association. While motivation and the level of EUC seems to be strongly linked, it is not clear if the EUC utilization is the source of the motivation, or the motivation is the source of the EUC utilization. Another study, perhaps in a more controlled environment such as a lab setting, could more definitely examine the association.

\section{References}

1. Alavi, M. and Weiss, I. "Managing the Risks Associated With End User Computing". Journal of Management Information Systems. 1985-1986. Winter. pp. 6-20.

2. $\quad$ Amoroso, D. "Organizational Issues in End User Computing". Database. 1988 Fall/Winter. pp. 49-57.

3. Arkush, E. and Stanton, S. "Measuring the Value of End User Computing". Journal of Information Systems Management. 1988. Fall. pp. 62-63.

4. Atwell, P and Rule, J. "Computing and Organization: What We Know And What We Don't Know". Communications of the ACM. 1984. vol. 27, no. 12. pp. 1184 - 1191.

5. Baroudi, J., Olson, M and Ives, B. "An Empirical Study of the Impact of User Involvement on System Usage and Information Satisfaction". Communications of the ACM. 1986. vol. 29, 3. pp. 232-238.

6. Baroudi, J. and Orlikowski, W. "A Short Form Measure of User Information Satisfaction: A Psychometric Evaluation and Notes on Use". Journal of Management Information Systems. 1989. March. pp. 45-59.

7. Baroudi, J. and Orlikowski, W. "The Problem of Statistical Power in MIS Research". MIS Quarterly. 1989. March. pp. 87-106.

8. Benjamin, R. "Information Technology in the 1990's: A Long Range Planning Scenario". MIS Quarterly. 1982 vol. 6, no. 2. pp. 11-26.

9. Bergeron, F. and Berube, C. "The Management of the End User Environment: An Empirical Study". Information and Management. 1988. Vol. 14, 1. pp. 107-113.

10. Blili, S., Raymond, L. and Rivard, S. "Definition and Measurement of End User Computing Sophistication." Journal of End User Computing. 1996. Vol. 8, no. 2. pp. 3-12.

11. Bostrom, R., Olfman, L. and Sein, M. "The Importance of Learning Style in End User Training". MIS Quarterly. 1990. Vol. 14, 1. pp. 101-119.

12. Brancheau, J. and Wetherbe, J. ""Key Issues In Information Systems Management". MIS Quarterly. 1987. Vol. 13, 3. pp. 23-37.

13. Brown. C. and Bostrom. R. "Effective Management of End User Computing: The Total Organizational Perspective". Information and Management. 1987 vol. 13, no. 3. pp. 233-243.

14. Cheney, P., Mann, R., and Amoroso, D. "Organizational Factors Affecting the Success of End User Computing". Journal of Management Information Systems. 1986. Vol. 3, 1. pp. 66-80.

15. Cougar, J. and Zawecki, R. Motivating and Managing Computer Personnel. 1980. (Wiley: New York).

16. Davis, G. and Olson, M. Management Information Systems: Conceptual Foundations and Theories. 1985 (McGraw-Hill: New York).

17. Deans, C., Ricks, D, Toyne, B., Goslar, M. and Karwan, K. "Identification of Key International Information Systems Issues in U.S. Based Multinational Corporations". Journal of Management Information Systems. 1991. Vol. 7, 4. pp. 1-24.

18. Doll, w. and Torkzadeh, G. "The Measurement of End User Computing Satisfaction". MIS Quarterly. 1988 vol. 12, no. 3. pp. 259-273.

19. Daft, R. Management. 1991 (Dryden Press: Chicago, Il.) pp. 37-39.

20. Eason, K. "Towards the Experimental Study of Usability". Behavior and Information Technology. 1984. vol. 3, no. 2. pp. 133-143. 
21. Franz, C., Robey, D. and Koeblitz, R. "User Response to an Online Information System: A Field Experiment". MIS Quarterly. 1986. vol. 10, 1. pp. 29-41.

22. Freedman, S. and Phillips, J. "The Effects of Situational Performance Constraints on Intrinsic Motivation and Satisfaction: The Role of Perceived Competence and Self-Determinism" Organizational Behavior and Human Decision Processes. 1985. vol. 35, no. 2. pp. 397-416.

23. Galletta, D. and Hufnagel, E. "A Model of End User Computing Policy". Information and Management. 1992. Vol. 22. pp. 1 - 18.

24. Gerrity, T. and Rockart, J. "End User Computing: Are You a Leader or a Laggard?" Sloan Management Review. 1986. Summer. pp. 503-517.

25. Hackathorn, R. "End User Computing by Top Executives". Database. 1988 vol. 19, no. 3-4. pp. 1-7.

26. Hackman, R. "Work Design". Motivation and Work Behavior. Steers, Richard and Porter, Lyman (eds.) 1987. (McGraw-Hill: New York). pp. 467-492.

27. Hackman, R. and Oldham, G. "The Development of The Job Diagnostic Survey". Journal of Applied Psychology. 1976 vol. 60, no 2. pp. 159-170.

28. Hackman, R. and Oldham, G. Work Redesign. 1980 (Addison-Wesley: Reading, Pa.).

29. Hayen, R., Cook, W. and Jecker, G. "End User Training in Office Automation: Matching Expectations". Journal of Systems Management. 1990. March. pp. 7-12.

30. Henderson, J. and Treacy, M. "Managing End User Computing for Competitive Advantage". Sloan Management Review. 1986. Winter. pp. 3-14.

31. Igbaria, M., Pavri, F., and Huff, S. "Microcomputer Applications: An Empirical Look at Usage". Information and Management. 1989, vol. 16, no. 4. pp. 586-603.

32. Jarvenpaa, S., Dickson, G. and DeSanctis, G. "Methodological Issues in Experimental IS Research: Experiences and Recommendations". MIS Quarterly. 1985, vol. 9, no. 2. pp. 141-156.

33. Karten, N. "Managing End User Computing When the only Constant is Change". Journal of Systems Management. 1987, October. pp. 26-29.

34. Karten, N. "Standards for User-Driven Application Development". Journal of Information Systems Management. 1991. Summer. pp. 60-62.

35. Karten, N. "The Myth of the Sophisticated User". Journal of Information Systems Management. 1988 winter. pp. 81-83.

36. Kraut, R. "Social Issues and White Collar Technology: An Overview". Technology and the Transformation of White Collar Work. Kraut, Robert, (ed.) 1987 (LEA Pub.:Hillsdale, NJ) pp. 211-235.

37. Martin, J. Application Development Without Programmers. 1982. (Prentice Hall: Englewood Cliffs, NJ).

38. Martin, J. An Information Systems Manifesto. 1984. (Prentice Hall: Englewood Cliffs. NJ).

39. Mcleod, R. Management Information Systems. 1995. (Prentice Hall: Englewood Cliffs, NJ.).

40. Medcorf, J. "The Effect of Extent of Use of Information Technology and Job of User on Task Characteristics". Human Relations. 1989. vol. 42, no. 1. pp. 23-41.

41. Millman, Z and Hartwick, J. "The Impact of Automated Office Systems on Middle Managers and Their Work". MIS Quarterly. 1987. vol. 11, 4. pp. 479-491.

42. Moore, G. "End User Computing and Office Automation: A Diffusion of Innovations Perspective". INFOR. 1987 vol. 25, no. 3. pp. 214-235.

43. Morieux, Y. and Sutherland, E. "The Interaction Between the Uses of Information and Organizational Culture". Behavior and Information Technology. 1988 vol. 7, no. 2. pp. 205-213.

44. Nelson, R. and Cheney, P. "Training End Users: An Exploratory Study". MIS Quarterly. 1987. vol. 11 , no. 4. pp. 547-559.

45. Nelson, D. "Individual Adjustment to Information Driven Technologies". MIS Quarterly. 1990. Vol. 14, 1. pp. 79-98.

46. Ngwenyama, O. "Developing End-users' Systems Development Competence". Information and Management. 1993. Vol. 25. pp. 291-302.

47. O'Donnell, D. and March, S. "End User Computing Environments - Finding a Balance Between Productivity and Control". Information and Management. 1987. vol. 13, no. 1. pp. 77-84.

48. Palvia, P. "On End User Computing Productivity". Information and Management. 1991. vol. 21. Pp. $217-224$.

49. $\quad$ Panko, R. "Issues and Directions in End User Computing". INFOR. 1987 vol. 25, no. 3. pp. 181-197. 
50. Panko, R. End User Computing. 1988. (Wiley: New York).

51. Rafali, A. and Sutton, R. "Word Processing and Perceptions of Control Among Clerical Workers". Behavior and Information Technology. 1986. vol. 5, 1. pp. 31-37.

52. Regan, E. and O'Connor, B. Automating the Office. 1989. (MacMillan: New York).

53. Rivard, S. "Successful Implementation of End User Computing". Interfaces. 1987. Vol. 17, 3. pp. $25-33$.

54. Rivard, S. and Huff, S. "User Developed Applications: Evaluations of Success from the DP Perspective". MIS Quarterly. 1984. vol. 8, no. 1. pp. 30-50.

55. Rivard, S. and Huff, S. "An Empirical Study of Users as Application Developers". Information and Management. 1985. vol. 8, no. 1. pp. 89-102.

56. Rivard, S. and Huff, S. "Factors for Success of End User Computing". Communications of the ACM. 1988. vol. 31, no. 5. pp. 552-561.

57. Rockart, J. and Flannery, L. "The Management of End User Computing". Communications of the ACM. 1983. vol. 26, no. 10. pp. 776-784.

58. Safeyani, F.; Purdy, L. and Higgins, C. "Social Meaning of Personal Computer for Managers and Professionals: Methodology and Results". Behavior and Information Technology. 1989. vol. 8, no. 2. pp. 99-107.

59. Sein, M and Bostrom, R. "Training End Users to Compute: Cognitive, Motivational and Social Issues". INFOR. Vol. 25, 3 pp. 236-254.

60. Sipior, J. and Sanders, G. "Definitional Distinctions and Implications for Managing End User Computing". Information and Management. 1989. vol. 16, 1. pp. 115-123.

61. Straub, D. "Validating Instrument in MIS Research". MIS Quarterly. 1989. vol. 13, no. 2. pp. $147-169$.

62. Sumner, M. and Klepper, R. "The Impact of Information Systems Strategy on End User Computing". Journal of Systems Management. 1987. October. pp. 12-17.

63. Taylor, J. "Job Design and the Quality of Work Life". Technology and the Transformation of White Collar Work. Kraut, Robert, (ed.) 1987 (LEA Pub. Hillsdale, NJ) pp. 211-235.

64. Thierauf, R. New Directions in MIS Management. 1988. (Quorom: New York).

65. Van Kirk, D. Poor Asset Management is Breaking the Bank. INFOWORLD. Jan. 3, 1995.

66. Yaverbaum, G. "Critical Factors in the User Environment: An Experimental Study of Users, Organizations and Tasks". MIS Quarterly. 1988 vol. 12, no. 2. pp. 75-88. 
Figure I

Hackman/Oldham Job Characteristics Model

Relating Job Core Characteristics to Job Outcomes

$\begin{array}{ll}\text { Core Job } & \text { Critical } \\ \text { Characteristics } & \text { Psychological } \\ & \text { States }\end{array}$

Outcomes

States

Skill Variety
Task Significance

\section{$\underline{\text { Moderators }}$}

1. Knowledge and Skills

2. Growth Need Strength

3. "Context" Satisfactions

\section{Table I}

Rockart and Flannery's

\section{Taxonomy of Levels of EUC Activity}

\footnotetext{
Level One:

Nonprogramming End User - Accesses and uses software provided by others.

Level Two:

Command Level User - uses data on own terms, utilizes report generators and/or limited command sets.

Level Three:

End User Programmer - Uses command and procedural languages to fulfill personal information needs. These applications may be used by others.

Level Four:

Functional support - supports other users on an informal basis; Personnel programs at a sophisticated level but is not considered IS personnel.

Level Five:

End User support - Specializes in EUC support. Normally a member of Information Center staff.

Level Six: $\quad$ DP Programmers - Performs like normal IS staff but programs only in EUC languages.
} 
Table II

Summary Description of End Users

\begin{tabular}{|l|c|c|c|}
\hline Sex & $\begin{array}{c}\text { Non programming } \\
\text { End User }\end{array}$ & $\begin{array}{c}\text { Command } \\
\text { Level User }\end{array}$ & $\begin{array}{c}\text { End User } \\
\text { Programmer }\end{array}$ \\
\hline \hline Female & 23 & 31 & 9 \\
\hline Male & 17 & 17 & 24 \\
\hline \hline Age & 11 & 16 & 16 \\
\hline \hline $20-29$ & 17 & 18 & 15 \\
\hline $30-39$ & 10 & 14 & 2 \\
\hline $40-49$ & 1 & 0 & 0 \\
\hline $50-59$ & 1 & 0 & 0 \\
\hline $60-$ UP & & & 19 \\
\hline \hline Industry & 27 & 23 & 11 \\
\hline \hline Service & 12 & 21 & 3 \\
\hline Manufacturing & 1 & 4 & 33 \\
\hline Non-Profit & 40 & 48 & \\
\hline \hline n & & & \\
\hline
\end{tabular}

Table III

User Mean Motivating Potential Score And Standard Deviation For Euc Levels

\begin{tabular}{|c|c|c|c|c|c|}
\hline & & $\begin{array}{c}\text { Sample } \\
\text { Mean }\end{array}$ & $\begin{array}{c}\text { Non } \\
\text { programming } \\
\text { End User }\end{array}$ & $\begin{array}{l}\text { Command } \\
\text { Level User }\end{array}$ & $\begin{array}{l}\text { End User } \\
\text { Programmer }\end{array}$ \\
\hline \multirow[t]{2}{*}{ MPS } & $\mathrm{X}$ & 147.1 & 127.7 & 149 & 173.2 \\
\hline & $\square:$ & 72 & & & \\
\hline \multirow[t]{2}{*}{$\begin{array}{l}\text { Skill } \\
\text { Variety }\end{array}$} & $\mathrm{X}$ & 5.5 & 4.92 & 5.47 & 5.7 \\
\hline & $\square:$ & 1.4 & & & \\
\hline \multirow[t]{2}{*}{$\begin{array}{l}\text { Task } \\
\text { Significance }\end{array}$} & $\mathrm{X}$ & 5.15 & 5.01 & 5.0 & 5.56 \\
\hline & $\square:$ & 1.4 & & & \\
\hline \multirow[t]{2}{*}{$\begin{array}{l}\text { Task } \\
\text { Identity }\end{array}$} & $\mathrm{X}$ & 5.1 & 4.7 & 5.3 & 5.3 \\
\hline & $\square:$ & 1.3 & & & \\
\hline \multirow[t]{2}{*}{ Autonomy } & $\mathrm{X}$ & 5.5 & 5.49 & 5.53 & 5.76 \\
\hline & $\square:$ & 1.1 & & & \\
\hline \multirow[t]{2}{*}{ Feed-back } & $\mathrm{X}$ & 4.86 & 4.63 & 4.75 & 5.3 \\
\hline & $\square:$ & 1.29 & & & \\
\hline \multirow[t]{2}{*}{$\begin{array}{l}\text { Growth Need } \\
\text { Strength }\end{array}$} & $\mathrm{X}$ & 5.65 & 5.57 & 5.82 & 5.49 \\
\hline & $\square:$ & 1.1 & & & \\
\hline
\end{tabular}


Table IV

Results Of Anova Testing For Motivating Potential Scores Job Core Characteristics And User Growth Need Strength

\begin{tabular}{||l|c|c|c||}
\hline \hline Variable & $\begin{array}{c}\text { Degrees Of } \\
\text { Freedom }\end{array}$ & T Value & Probability \\
T
\end{tabular}

Table V

Results Of Scheffe's Paired Comparisons Test For Differences Between EUC Levels

\begin{tabular}{|l|c|c|c|}
\hline & Level 1/2 & Level 2/3 & Level 1/3 \\
\hline MPS & No & No & Yes \\
\hline Skill Variety & Yes & No & Yes \\
\hline Task Significance & Yes & Yes & Yes \\
\hline Task Identity & & \multicolumn{2}{|c|}{-- No Differences -- } \\
\hline Autonomy & No & Yes & Yes \\
\hline Feedback & & - No Differences - & \\
\hline GNS & &
\end{tabular}

Level 1 Nonprogramming End User.

Level 2 Command Level User.

Level 3 End User Programmer. 
Notes 